\title{
Wessex and the Reign of Edmund II Ironside
}

\author{
David McDermott
}

Edmund Ironside, the eldest surviving son of Æthelred II ('the Unready'), is an often overlooked political figure. This results primarily from the brevity of his reign, which lasted approximately seven months, from 23 April to 30 November 1016. It could also be said that Edmund's legacy compares unfavourably with those of his forebears. Unlike other Anglo-Saxon Kings of England whose longer reigns and periods of uninterrupted peace gave them opportunities to legislate, renovate the currency or reform the Church, Edmund's brief rule was dominated by the need to quell initial domestic opposition to his rule, and prevent a determined foreign adversary seizing the throne. Edmund conducted his kingship under demanding circumstances and for his resolute, indefatigable and mostly successful resistance to Cnut, his career deserves to be discussed and his successes acknowledged.

Before discussing the importance of Wessex for Edmund Ironside, it is constructive, at this stage, to clarify what is meant by 'Wessex'. It is also fitting to use the definition of the region provided by Barbara Yorke. The core shires of Wessex may be reliably regarded as Devon, Somerset, Dorset, Wiltshire, Berkshire and Hampshire (including the Isle of Wight). ${ }^{1}$ Following the victory of the West Saxon King Ecgbert at the battle of Ellendun (Wroughton, Wilts.) in 835 , the borders of Wessex expanded, with the counties of Kent, Sussex, Surrey and Essex passing from Mercian to West Saxon control. ${ }^{2}$

Wessex was not the only region with which Edmund was associated, and nor was he the only king from the royal House of Wessex with connections to other regions. The Anglo-Saxon Chronicle records that Æthelstan, who was probably raised in Mercia, was chosen by the Mercians to succeed Edward the Elder. ${ }^{3}$ Edmund's grandfather, Edgar, had been fostered by Ealdorman Athelstan of East Anglia, and was accepted by the Mercians as king in their region

1 Barbara Yorke, Wessex in the Early Middle Ages (Leicester, 1995), p. 1.

2 ASC A E 835; trans. Michael Swanton (London, 2000), pp. 6o-61; B.A.E. Yorke, “Wessex," in The Blackwell Encyclopaedia of Anglo-Saxon England, ed. Michael Lapidge, John Blair, Simon Keynes and Donald Scragg (Oxford, 1999), p. 470-71, at p. 471.

3 AsC C D 924; trans. Swanton, p. 105; also Sarah Foot, Ethelstan: The First King of England (New Haven, 2011), pp. 17-18 and 34-35. 
prior to him succeeding his brother as king of all England. ${ }^{4}$ Similarly, a connection between Edmund and Mercia can be found early in his career. Shortly after marrying the widow of the murdered Mercian thegn Sigeferth, Edmund took possession of Sigferth's lands, and those of his murdered brother Morcar. ${ }^{5}$ Mercia became Edmund's temporary power base, provided the ætheling with three armies, raised to oppose the depredations of Cnut. ${ }^{6}$ When each of these armies failed to engage with the Danes, Edmund sought assistance from another region and entered into an alliance with his brother-in-law, Earl Uhtred of Northumbria. Together they raided territories controlled by Earl Eadric of Mercia, until Uhtred was compelled to abandon the joint-campaign to protect his earldom and Edmund returned to London. ${ }^{7}$

Upon his accession however, Edmund was more closely associated with Wessex than any other region, and relied on its resources to defend his kingship. The relationship between Edmund Ironside and Wessex was cyclical and reciprocal. It is most likely that Edmund was born and raised in the region and, given that he was buried in Glastonbury, it is probable that he died in Wessex. It is also notable that the rebellion of the ætheling Edmund began in Wessex. The influence Wessex exerted on the ætheling Edmund was reciprocated when he became king. Edmund restored English rule to areas of Wessex that had submitted to the Danes. The region also contributed to the posthumous reputation of Edmund, and in the division of the kingdom in 1016, Edmund received Wessex.

The precise location and date of Edmund's birth are unknown but there is strong circumstantial evident to suggest that he was born and raised in Wessex. Edmund's name, and that of two older brothers and one younger brother, first appears in a diploma indicating the return to court, after a period of retirement at Wherwell, of dowager Queen Ælfthryth. ${ }^{8}$ The implication of Ælfthryth's reappearance, and the first attestations of Æthelred's four oldest sons, suggests that they were raised in the nunnery which the queen had founded. Further evidence that Edmund was raised by his grandmother, in Wessex, is suggested

4 ASC B C 957; D s.a. 955, p. 113; also Cyril Hart, "Athelstan 'Half King' and his Family," in The Danelaw (London, 1992), pp. 569-604.

5 ASC E 1015; p. 146.

6 ASC D E 1015-16; pp. 146-47.

7 ASC D E 1016; pp. 147-49. Further details of Edmund's campaign with Uhtred can be found in WM, GRA, pp. 312-13; JW vol. 2, pp. 482-83.

8 S 876 (AD 993); for Ælfthryth's foundation of Wherwell see S 904 (AD 1002). Also Pauline Stafford, "Sons and Mothers: Family Politics in the Early Middle Ages," in Medieval Women: Essays Dedicated and Presented to Professor Rosalind M.T. Hill ed. Derek Baker, Studies in Church History: Subsidia 1 (Oxford, 1978), pp. 79-100, at p. 95 . 
by the will of Edmund's older brother Athelstan. The will of the senior ætheling asserts that he was "brought up" (afedan) by Ælfthryth. ${ }^{9}$ Queen Ælfthryth possessed a number of estates throughout Wessex which, as has been observed by Pauline Stafford, suggests that Edmund's grandmother had sufficient resources to raise the children of Æthelred's first marriage, and that Edmund may have spent part of his childhood somewhere other than Wherwell. ${ }^{10}$ Simon Keynes and Ann Williams have independently nominated Ethelingadene (Singleton, West Sussex), as a highly probable alternative setting for the æthelings' upbringing. ${ }^{11}$ As indicated previously, Sussex was not one of the core shires of Wessex but had been absorbed by the region in the early 9th century. It is not known when Ælfthryth received this estate, but her possession of it is deduced from Æthelred granting sixty hides at Ethelingadene, which previously belonged to Queen Ælfthryth, to Abbess Heanflæd and Wherwell Abbey. ${ }^{12}$

Ethelingadene may have been significant for the young Edmund Ironside when it was attacked by a Viking raiding party in $1001 .^{13}$ It is not known if Edmund was present during the raid, or the reason for it, but Ryan Lavelle makes the persuasive suggestion that the assailants of Æthelingadene may have understood the political significance of assaulting an important royal estate. ${ }^{14}$ It also possible that Ethelingadene's connection with the royal children, who

$9 \quad \mathrm{~S}_{1503}$, trans. as "Old English will of the Atheling Athelstan, eldest son of King Ethelred (1014)," in $E H D$ 1, pp. 593-96, at p. 596. The verb afedan can mean 'feed' and 'maintain' but in the context of upbringing, 'brought up' is perhaps the better interpretation; see J.R. Clark Hall, A Concise Anglo-Saxon Dictionary, 4th ed. (Toronto, 2008), p. 14; Stafford, "Sons and Mothers" pp. 92, 95; Ann. Williams, Ethelred the Unready: The Ill-Counselled King (London, 2003), p. 28; Ryan Lavelle, Royal Estates in Anglo-Saxon Wessex: Land, Politics and Family Strategies, BAR Brit. Ser., 439 (Oxford, 2007), p. 91.

10 Stafford, "Sons and Mothers" p. 92. For the diploma evidence of Ælfthryth's other estates, see S 725 (AD 964), S 742 (AD 966), and S 877 (AD 966). For lands held by Ælfthryth, see Lavelle, Royal Estates, pp. 11 and 84-89.

11 Simon Keynes, The Diplomas of King Ethelred "The Unready," 978-1016: A Study in Their Use as Historical Evidence (Cambridge, 1980), p. 187, n.117; Williams, Ethelred the Unready, pp. 28 and 162, n.55. For further discussion of Ethelingadene, see Ryan Lavelle, "Places I'll Remember? Reflections on Alfred, Asser and the Power of Memory in the West Saxon Landscape," above, pp. 323-25.

12 S 904.

13 ASC A 1001, p. 132.

14 R. Lavelle, Aethelred II: King of the English 978-1016 (Stroud, 2002), p. 85. Williams suggests that Elfthryth may have been alive in 1001 and therefore still owned Ethelingadene; Ethelred the Unready, p. 50, n. 42. 
were a potentially powerful bargaining tool if taken hostage, may have increased the possibility of attack..$^{5}$

Through his grandmother, Edmund was also connected to a powerful family in the West Country. His great grandfather, Ordgar, had been an influential and important figure in south-west England, and in one of King Edgar's diplomas Ordgar attests as the Ealdorman of Devon (dux Domnonice). ${ }^{16}$ It has been plausibly suggested, by Stafford, that Ordgar's appointment and Ælfthryth's marriage to King Edgar, may have been part of a policy to attract allies in the South West of England. ${ }^{17}$ Edmund's great uncle, Ordwulf, did not inherit the office of ealdorman but his occupancy of a position of responsibility is indicated by John of Worcester's description of Ordwulf as "first amongst the men of Devon" (Domnanie primas) $)^{18} \mathrm{He}$ may also, as suggested by Williams, have been reeve of the royal manor of Lipton in Devon. ${ }^{19}$

Edmund's connections to the nobility of the West of England are further demonstrated in his lease for Holcombe Rogus (formerly Dorset, now Devon), acquired from the community of Sherborne. ${ }^{20}$ Diploma evidence indicates that several ecclesiastical and lay witnesses to the lease were connected to Edmund in other contexts. Bishop Lyfing of Wells attested diplomas with Edmund prior to the ætheling acquiring Holcombe ${ }^{21}$ and within the termini ante and post quem of the lease. ${ }^{22}$ After he became Archbishop of Canterbury, Lyfing attested one other diploma with Edmund. ${ }^{23}$

The attestation of Bishop Æthelric of Sherborne is to be expected but Edmund's connection to the bishop was not confined to the lease. Bishop Æthelric attested all but three of the diplomas witnessed by Edmund and Bishop Lyfing, and witnessed one diploma with Edmund not attested by Bishop

15 Accounts of the capture of hostages (as opposed to hostages given as guarantees) are rare in Anglo-Saxon England: in an attack on Brycheiniog, Æthelflæd is reported to have taken the Welsh king's wife, amongst others, as hostage, perhaps in retaliation for the killing of Abbot Ecgberht: ASC C 916; p. 100; see also the seizure by Vikings of Archbishop Ælfheah of Canterbury (for ransom?) in ASC CDE 1011.

16 S 741 (AD 966).

17 Pauline Stafford, Unification and Conquest: A Political and Social History of England in the Tenth and Eleventh Centuries (London, 1989), pp. 52-53.

18 JW vol. 2, p. 447 .

19 Williams, Ethelred the Unready, p. 29.

$20 \quad S_{1422}$ (AD 1007×1014). The Charters of Sherborne, ed. M.A. O'Donovan, Anglo-Saxon Charters 3 (Oxford, 1988), no. 14 .

21 S 989-901 (AD 1001-112); S904 (AD 1002); 906 (AD 1004) and S 910-12 (AD 1005).

22 S 915 (AD 1007); S 920-23 (AD 1008-1011); S 929 (AD 1012); S 931 (AD 1013) and S 933 (AD 1014).

$23 \quad \mathrm{~S} 934$ (AD 1015). 
Lyfing. ${ }^{24}$ Edmund probably had considerably less contact with Bishop Æthelsige of Cornwall, who also witnessed the Holcombe lease. Edmund and Æthelsige are known to have attested only two diplomas together. ${ }^{25}$ This suggests strongly that Æthelsige's association with Edmund was significantly weaker than that of Bishop Lyfing, who witnessed sixteen diplomas with the ætheling, and Bishop Æthelric, who witnessed fourteen.

The most prestigious member of the Wessex nobility to attest Edmund's lease was arguably Æthelmær, Ealdorman of the Western provinces. There is evidence to suggest that Edmund and Æthelmær may have known each other prior to the lease, as an Æthelmær minister (thegn) witnessed several diplomas with Edmund between 993-1005. ${ }^{26}$ Æthelred's diplomas also indicate Edmund was associated with another West Country thegn, also called Æthelmær. This second Æthelmær witnessed diplomas with Edmund before and after the ætheling acquired Holcombe. ${ }^{27}$ The identically named thegns also attested diplomas with Bishops Lyfing and Æthelric, and some of those diplomas concern estates in the west of England. ${ }^{28}$

The remaining West Country noble who may have known Edmund independently of the lease is the enigmatically named Dorset thegn Brihtric the Red (reada). It is possible that the same Brihtric, without his soubriquet, witnessed diplomas with Edmund. ${ }^{29}$ Approximately half of these diplomas refer to estates in the west of England, suggesting that the Brihtric who witnessed at Holcombe is the same man who attested the other diplomas with Edmund. ${ }^{30}$ Also mentioned in the Holcombe lease are several West Country witnesses for whom there are no other references in the historical record: Abbot Leofsunu of Cerne; Æthelfand, the son of Æthelmær, Ealdorman of the Western Provinces; Ælfgeat, son of Hength; and Siweard.

The attestation of Abbot Leofsunu, the senior ecclesiastic in Dorset, might be expected; and Æthelfand, the son of the most senior noble in the region, may have accompanied his father to witness the lease. ${ }^{31}$ The reference in the lease to "all the foremost thegns of Dorset" (ealle pa ildostan Jcegnas on Dorsceton) is

\footnotetext{
24 S 900-01; S 904; S 906; S 910-12; S 915; S 920-24 and S 933.

$25 \quad S 922$ and $S 924$.

26 S 876; S 878 (AD 996); S 891 (AD 997); S 893 (AD 998); S 898-901; S 904; S 906 and S 910.

27 S 878; S 893; $\mathrm{S}$ 901; $\mathrm{S}$ 906; $\mathrm{S}$ 910-12; S 916 (AD 1007) and S 921-22.

28 The first Æthelmær attested the granting of West Country estates in S 899 and S 910; the second Æthelmær attested the granting of West Country estates in S 910 and 921.

29 S 891; S 901; S 904; S 910-12 and S 921.

30 The West Country estates appear in S 904; S 910 and S 921.

31 The otherwise unknown Æthelfand may be a scribal error for Æthelmær's son Æthelweard: Williams, Ethelred the Unready, p. 114 and n. 23.
} 
immediately preceded by the names Ælfgeat and Siweard. They were perhaps indigenous Wessex aristocracy and the appearance of their names may also indicate they had seniority amongst the thegns.

\section{Rebellion}

Wessex assumed greater significance for Edmund when it witnessed his initial acts of rebellion. The catalyst for Edmund's revolt appears to have been the execution of Edmund's long-standing associates, the Mercian thegns Sigeferth and Morcar. Edmund's response to the thegns' deaths, the confiscation of their possessions and the sequestration of Sigeferth's widow at Malmesbury was decisive, dramatic and criminal. Edmund released the widow and married her contrary to Æthelred's will. ${ }^{32}$

The king's motives for transferring the widow from Mercia to Wessex are not revealed in the laconic account of the Anglo-Saxon Chronicle but political considerations may have informed Æthelred's thinking. The Chronicle describes Sigeferth and Morcar as amongst the "foremost thegns" (yldestan pregenas) of their region, suggesting that they and their family exercised considerable influence and commanded significant support. ${ }^{33}$ Faced with the possibility of Sigeferth's widow becoming the focus for protest against the thegns' executions, Æthelred may have removed the widow to Wessex where she would effectively be a hostage for the good behaviour of her family.

Æthelred's reason for choosing Malmesbury is also unknown, but several factors may have made it an attractive location in Wessex to secure the lady. Malmesbury is close to the Fosse Way, along which Sigeferth' widow might have been taken from the Midlands to Wessex. The town was also a burh, providing those responsible for safeguarding the lady with a defensible position to resist attempts to remove her. References in the Anglo-Saxon Chronicle to Malmesbury as the town of Ealdhelm, the first abbot of Malmesbury, might indicate, as has been suggested by Susan Kelly, that the lady may have been placed in the minster or a royal residence in the town. ${ }^{34}$

$32 \quad A S C$ E 1015. The Chronicle does not record the reasons for the thegns' deaths but possible explanations can be found in: Stafford, "The Reign of Æthelred II," pp. 35-37; Unification and Conquest, p. 68; Charles Insley, "Politics, Conflict and Kinship in Eleventh Century Mercia," Midland History 25 (2000), 28-42., at pp. 31 and 34-35.

$33 \quad A S C$ E, p. 146.

34 ASC CE 1015; S.E. Kelly, Charters of Malmesbury Abbey, Anglo-Saxon Charters 11 (Oxford, 2005), p. 26. 
In releasing Sigeferth's widow from her confinement, Edmund frustrated Æthelred's intention that she be sequestered. The legality of Edmund defying his father is a moot point, but removing the widow was a criminal act. Sigeferth's widow was technically under Æthelred's protection, and by taking her Edmund was in breach of the law. ${ }^{35}$ Edmund's marriage to the widow was also unlawful. ${ }^{36}$ The same law code that afforded protection to widows also forbade a woman to remarry within a year of her husband's death. ${ }^{37}$ When Edmund married Sigeferth's widow, the stipulated time had not elapsed, making his union illicit. ${ }^{38}$

\section{Wessex and the Legitimation of Power}

Following his rebellion in Wessex, Edmund became more closely involved with other regions of the country. He cultivated his relationships in Mercia and fought a campaign in the region with Uhtred of Northumbria. With the death of Æthelred on 23 April, Edmund returned his attention to Wessex. After his election in London, Edmund went into Wessex where the population ostensibly submitted to him. ${ }^{39}$ Edmund's entry into the region, as described in the Anglo-Saxon Chronicle, is typically laconic but potentially deceptive. As Williams has suggested, the Old English 'gerad', used to describe how Edmund entered Wessex, may derive from the verb 'ridan', meaning 'to seize' or 'to occupy'. If correct, Edmund may have exercised force, implying that at least some parts of the region opposed his rule. ${ }^{40}$

35 See Æthelred's law code $V$ Æthelred, in A.J. Robertson, ed., The Laws of the Kings of England From Edmund to Henry I (Cambridge, 1925), pp. 85; 102. Wealthy widows in AngloSaxon England were sometimes the target of fortune hunters; T.J. Rivers, "The Legal Status of Widows in Late Anglo-Saxon England," Medievalia et Humanistica 24 (1997), 1-16, at p. 1; Christine Fell, Women in Anglo-Saxon England (Cambridge, 1984), p. 61; Sarah Foot, Veiled Women, 1: The Disappearance of Nuns from Anglo-Saxon England (Aldershot, 2000), p. 121.

36 Æthelred's reason for objecting to the marriage have been speculated upon by Stafford, "Sons and Mothers," p. 95 and n. 59; N.J. Higham, The Death of Anglo-Saxon England (Stroud, 1997), p. 62.

$37 \quad$ VEthelred, in Robertson, Laws, p. 85.

38 None of Æthelred's extant law codes specify the punishment for a widow who re-married within the prescribed period but Cnut, perhaps in response to Edmund's marriage, introduced severe sanctions for the offence; see II Cnut, in Robertson, Laws, p. 211.

39 ASC, D E F 1016; pp. 148-49.

40 Williams makes a comparison with the modern terms 'override' and 'ride roughshod over'; Ethelred the Unready, pp. 142-43 and p. 226 n. 63. Lavelle makes a compelling case that the verb "geridan," used in the ASC to describe Alfred's control of Wessex, might indicate the chronicler's support for Alfred's kingship; “Geographies of Power in the Anglo-Saxon 
John of Worcester's unique 12th-century account of Edmund's reception in Wessex may also obscure the truth and exaggerate his popularity in the region. Edmund is recorded as being received with great joy, with many hastily submitting to him voluntarily. This may be a literary trope, intended to convey the legitimacy of Edmund's accession, but another passage from this AngloNorman narrative makes the reliability of Edmund's alleged rapturous welcome questionable. John of Worcester also records that the bishops, abbots, ealdormen and all the nobles of England elected Cnut to be their lord and king at Southampton. ${ }^{41}$

The alleged double-election, as Williams suggests, may be a misplaced repetition of the submission made to Cnut after Edmund's death. There may however be some factual basis for John of Worcester's account. The submission of the senior clergy and nobility to Cnut at Southampton, it is argued, would explain Edmund's probable subjugation of Wessex. ${ }^{42} \mathrm{Had}$ Cnut been elected, Edmund's arrival in Wessex may not have been received with unqualified enthusiasm. It is more probable, suggests Jeffrey James, that the nobility of the region renounced their pledges to Cnut and accepted Edmund's lordship, under penalty of death. ${ }^{43}$ The possibility that parts of Wessex had capitulated to Cnut, which Edmund then had to re-take, may also receive some support from William of Malmesbury's reference to Cnut taking possession of cities and towns while the ætheling Edmund was raising armies against him. ${ }^{44}$

Soon after securing the submission of Wessex, according to the Anglo-Saxon Chronicle, Edmund fought the first of his battles in the region, at Penselwood in Dorset. ${ }^{45}$ The proximity of Penselwood to the boundaries of Dorset, Somerset and Wiltshire may indicate, as suggested by Edward Freeman, that Edmund recruited his army from those shires. ${ }^{46}$ In addition to Penselwood occupying a ridge of high ground next to forest, other factors may have contributed to it being selected as a battle site. John Baker and Stuart Brookes, in the course of

Chronicle: The Royal Estates of Anglo-Saxon Wessex," in Reading the Anglo-Saxon Chronicle: Language, Literature, History, ed. Alice Jorgensen (Turnhout, 2010), pp. 187-219, at p. 207. This argument can be applied to Edmund to suggest the chronicler's endorsement of Edmund's rule.

41 JW vol. 2, pp. 484-85.

42 Williams, Ethelred the Unready, p. 140.

43 Jeffrey James, An Onslaught of Spears: The Danish Conquest of England (Stroud, 2013), p. 169 .

44 WM, GRA, pp. 312-13.

$45 \quad A S C$, D E 1016; p. 149.

46 E.A. Freeman, History of the Norman Conquest of England, its Causes and its Results, 6 vols (Oxford, 1862-76), 1:421-22. 
their continuing research into Anglo-Saxon assembly sites, have identified a small group of Anglo-Saxon meeting-places that are highly distinguishable by their domination of the landscape.

One such feature, termed a 'hanging promontory', lies just one kilometre to the south-east of Penselwood. ${ }^{47}$ Adjacent to the county boundaries of Dorset and Somerset, Moot Hill Piece is described as a possible 'supraregional' assembly site and may have provided Edmund with a mustering point for his army. Alternatively, Edmund's army may have mustered one kilometre to the northeast of Penselwood at Coombe Street, one of the possible locations of Egbert's Stone where King Alfred assembled the armies of Somerset, Wiltshire and Hampshire west of Southampton Water, prior to defeating the Danes at the Battle of Edington. ${ }^{48}$

It is also conceivable that Edmund stayed at the nearby royal estate at Gillingham, using its resources to entertain and feed his closest followers, in much the same way as did Alfred during the campaign that culminated at Edington. ${ }^{49}$ The importance of royal estates, as has been discussed by Lavelle, were essential to the maintenance of kingship and was one of the means by which the king expressed his legitimacy to rule. ${ }^{50}$ In his possible use of assembly sites and royal estates, Edmund Ironside may have exploited the landscape of Wessex to assert his kingship.

The Anglo-Saxon Chronicle is unusually terse in its account of Penselwood, simply recording that Edmund fought there. Written more than one hundred years after the events they purport to describe, the Anglo-Norman narratives are virtually identical in making Edmund the victor. ${ }^{51}$ Their reasons for doing so may be explained by Stafford's perceptive summary of the writing of history in 12th-century England. Part of the Anglo-Norman historians' purpose, it is argued, was to commemorate the Anglo-Saxon past. ${ }^{52}$ When their sources were quiescent on the outcome of Penselwood, it is possible that the 12thcentury apologists for pre-Norman England attributed a victory to Edmund.

47 John Baker and Stuart Brookes, "Monumentalising the Landscape: A Special Class of Anglo-Saxon Assembly Sites," AntJ 94 (2013), 1-16, at pp. 3-5.

48 ASC, MS. A, p. 76; John Baker and Stuart Brookes, "Identifying Outdoor Assembly Sites in Early Medieval England," Journal of Field Archaeology 40:1 (2015), 3-21, at p. 14.

49 Æthelweard, Chronicle, ed. A. Campbell (London, 1962), p. 42; Lavelle, Alfred's Wars, pp. 110 and 180.

5o Ryan Lavelle, "The Farm of One Night and the Organisation of Royal Estates in Late Anglo-Saxon Wessex," HSJ 14 (2005 for 2003), 53-82; "Geographies of Power," p. 206.

$5^{1} \quad$ WM, GRA, pp. 314-15; JW vol. 2, pp. 486-87; HH, pp. 356-57.

$5^{2}$ Stafford, Unification and Conquest, p. 20. 
Edmund and Cnut remained in Wessex, for the Anglo-Saxon Chronicle records that they next fought at Sherston (Wilts.). The proximity of Sherston to the borders of modern day Wilshire, Somerset and Gloucestershire, in what may be considered the western marches of Wessex, has led Freeman and Williams to suggest, independently, that the more easterly parts of the region may have been under Danish control. ${ }^{53}$ Sherston's shared county borders may also indicate it was close to a mustering point. The logistical advantage of a serviceable road, provided by the neighbouring Fosse Way, may also have commended Sherston to Edmund and Cnut as the location for their next encounter.

The probability that Wessex was divided in supporting Edmund in Wessex is indicated by John of Worcester. In an apparent address delivered by Eadric to Edmund's army, the ealdorman exhorted the men of Dorset, Devon and Wiltshire to flee the battlefield. ${ }^{54}$ The attribution of the address may be fiction but the content of the exhortation, suggests Williams, could indicate that not only eastern but central Wessex were in the possession of the Danes. ${ }^{55}$ In addition to the counties named by John of Worcester, Freeman argued that Edmund also recruited in Somerset. Lying between Wiltshire and Devon, it is plausible that Somerset contributed to the English army at Sherston. ${ }^{56}$

The presence of other English defectors amongst the Danish ranks at Sherston further illustrates the factionalism of Wessex. The Anglo-Saxon Chronicle identifies a certain Ælfmær Darling, ${ }^{57}$ and John of Worcester refers to the rebel Ælfgar, son of Meaw. ${ }^{58}$ Ælfmær Darling is unknown outside the context of Sherston but in the opinion of Timothy Bolton, the inclusion of Ælfgar is significant. Although he was a Gloucestershire magnate, Ælfgar also held several estates in Dorset and Devon. ${ }^{59}$ If Ælfgar recruited from these shires it would further illustrate the political fracturing of Wessex, and the difficulty Edmund had asserting his authority in the region.

The Danish army was also augmented, according to John of Worcester, by the men of Hampshire and Wiltshire. ${ }^{60}$ It may be expected that Hampshire,

\footnotetext{
53 Freeman, History of the Norman Conquest, 1:423; Williams, Ethelred the Unready, p. 143.

54 JW vol. 2, pp. 488-89.

55 Williams, Ethelred the Unready, p. 143.

56 Freeman, History of the Norman Conquest, 1:423.

57 ASC D E 1016; pp. 150-51.

$5^{8}$ JW vol. 2, pp. 486-87.

59 Timothy Bolton, The Empire of Cnut the Great: Conquest and the Consolidation of Power in Northern Europe in the Early Eleventh Century (Leiden, 2009), pp. 38-39.

6o JW vol. 2, pp. 486-87.
} 
which, according to John of Worcester, hosted the alleged submission to Cnut, would support the Danes. The presence of the men of Wiltshire, who also supported Edmund, indicates the county was divided in its allegiance. The Anglo-Norman accounts of English opposition to Edmund, if reliable, demonstrate that despite the claims of the Anglo-Saxon Chronicle that all of Wessex submitted to Edmund there was, as observed by Williams, resistance to Edmund's rule. ${ }^{61}$ English collaboration, as recorded in the Anglo-Norman narratives, does not necessarily indicate widespread rejection of Edmund. Antipathy to Edmund, Bolton suggests, appears to have been confined to southern Mercia and Wessex, and aversion to him may have been restricted to a small group with particular grievances. ${ }^{62}$

Edmund's second battle in Wessex seems to have ended inconclusively. The Anglo-Saxon Chronicle refers to the comparable loss of life on both sides, and the apparent consensus of the combatants to cease hostilities and separate. ${ }^{63}$ Similarly, William of Malmesbury does not award a clear victory to either side but makes the tantalising, and taciturn, remark that the English had hope of victory ${ }^{64}$ The unexplained expectation of the English, according to William, was sufficiently potent for the rebellious West Saxons to acknowledge Edmund as their rightful lord. ${ }^{65}$ This account is unique but repeated references to Edmund raising further armies in Wessex suggest that after Sherston his position in Wessex had become more secure. 66

A moral victory for Edmund at Sherston may be inferred from John of Worcester's assertion that during the night Cnut ordered his men to leave camp silently. ${ }^{67}$ The alleged purpose of the nocturnal departure was to renew the siege of London, but Cnut's insistence on stealth was seized upon by Freeman to give the 'practical advantage' to the English. ${ }^{68}$ To have left Edmund in possession of the battlefield, the traditional indication of success in war, may be interpreted as a Pyrrhic victory for the English. In practical terms, Edmund could exert his authority throughout Wessex and consequently recruit successive armies from a much wider area. The campaign in Wessex proved to be

\footnotetext{
$61 \quad$ Williams, Ethelred the Unready, p. 143.

62 Bolton, The Empire of Cnut, p. 38.

63 ASC D E 1016; pp. 150-51.

64 WM, GRA, pp. 314-15.

65 WM, GRA, pp. 314-15.

66 The Encomium Emmae Regince, ed. and trans. Alistair Campbell, Camden 3rd Ser. 72 (London, 1949), p. 21, records a Danish victory at Sherston but the panegyric nature of the narrative and significant factual errors, suggest its account of the battle is unreliable.

67 JW vol. 2, pp. 488-89.

68 Freeman, History of the Norman Conquest, 1:425.
} 
pivotal for Edmund's kingship providing him, according to Williams, a "platform" which facilitated his continued resistance to Cnut. ${ }^{69}$

\section{A Broader Perspective}

Edmund's remaining battles were fought outside Wessex but the region continued to have significance for him. The army gathered to follow Cnut and relieve his siege of London, according to John of Worcester, was assembled in Wessex. ${ }^{70}$ This is consistent with Edmund's last known location but the puzzling reference by another Anglo-Norman chronicler, Henry of Huntingdon, to Edmund relieving the siege with a team of "chosen warriors" requires scrutiny. ${ }^{71}$ Henry does not disclose the origin of this mysterious group but an answer may be found in the closely contemporary account of Thietmar of Merseburg.

The army that relieved Cnut's second siege of London, according to Thietmar, contained a contingent of "Britons" (Britannis). ${ }^{72} \mathrm{~A}$ similar reference to Danish swords striking 'British ring-shirts' (brezkum brynjum) at the siege of London is also contained in the Liðsmannaflokkr, which Russell Poole has convincingly argued was composed circa 1017 by Cnut's following. ${ }^{73}$ Collectively, these references may indicate that Edmund had recruited in the most westerly reaches of Wessex where the population was more likely to be of Welsh, that is, British, descent.

Evidence that connects Edmund to the more Celtic parts of Wessex may also be found in a diploma of Cnut, confirming a grant made by Edmund in exchange for land he had held in Cornwall. ${ }^{74}$ An entry in the Anglo-Saxon Chronicle referring to Cornwall as 'West Wales' indicates that in the early gth century it had remained sufficiently Celtic to be considered non-English, but following King Ecgberht's victory at Hingston Down, Cornwall nominally came under English rule. ${ }^{75}$ Henry of Huntingdon's enigmatic allusion to select warriors

\footnotetext{
69 Williams, Ethelred the Unready, p. 143.

70 JW vol. 2, pp. 488-89.

71 HH, pp. 356-57.

72 Thietmar of Merseburg, Thietmari Merseburgensis Episcopi Chronicon, ed. R. Holtzmann, MGH Scriptores rerum Germanicarum, nova ser. 9 (Berlin, 1935), chapter 41, p. 449.

73 Russell Poole, "Skaldic Verse and Anglo-Saxon History: Some Aspects of the Period 10091016," Speculum 62:2 (1987), 265-98, at pp. 282-84 and 286.

74 S 951 (AD 1018).

75 ASC A 828 [recte 83o]; p. 62 and n.9. Also, O.J. Padel, "Cornwall," in Blackwell Encyclopaedia of Anglo-Saxon England, pp. 122-23; T.M. Charles-Edwards, Wales and the Britons 350-1064 (Oxford, 2013), pp. 431; 494; 512-13.
} 
may therefore refer to a substantially 'West Welsh' section of Edmund's army that distinguished itself at London.

The reliance Edmund placed upon Wessex to supply him with fighting men is further demonstrated at the conclusion of the Battle of Brentford, fought two days after the expulsion of the Danes from London. Whether it was the result of men drowning in the Thames, as recorded in the Anglo-Saxon Chronicle, or losing men in the fighting as argued, independently, by Frank Stenton and Russell Poole, the Chronicle records that Edmund returned to Wessex and assembled another army. ${ }^{76}$ Upon his return, the Anglo-Saxon Chronicle describes Edmund as bringing an army gathered from 'the entire English nation'. This is probably an exaggeration but may indicate that Edmund augmented his force by recruiting from areas close to Wessex. ${ }^{77}$

The numerically impressive force encountered the Danes in Kent where, according to the Anglo-Saxon Chronicle, they fled to the Isle of Sheppey. ${ }^{78}$ The Chronicle is silent concerning Edmund's whereabouts until Assandun, but John of Worcester reports that after he had dispersed the Danes in Kent, Edmund returned to Wessex. ${ }^{79}$ This account is uncorroborated but Edmund's presence in Wessex would explain the Anglo-Saxon Chronicle recording that Edmund was initially unaware of Cnut raiding in Mercia. Edmund is said to have raised another army drawn from 'the entire English nation'80 to pursue Cnut but as before, this phrase should not be read literally but indicates that support for Edmund's extended beyond Wessex.

Support for the implication that Edmund had extended his kingship to other regions of the country, can be inferred by the names of the English known to have died at Assandun. The majority were men of Mercia: Ealdorman Godwine of Lindsey; Ulfcytel of East Anglia; Æthelweard, son of Ealdorman Æthelwine of East Anglia, and Abbot Wulfsige of Ramsey. The location of Assandun in Essex may explain the apparent dominance of Mercians but the death-roll in the Anglo-Saxon Chronicle suggests that Wessex incurred the second highest

76 ASC D E 1016; pp. 150-51; Frank Stenton, Anglo-Saxon England, 3rd ed. (Oxford, 1971), p. 391; Poole, "Skaldic Verse," p. 275.

ASC D E 1016; p. 150-51. One should not, as Richard Abels advises, read the Chronicle too literally: the reference to the "entire English nation" probably refers only to those who had a military obligation to attend the summons; Lordship and Military Obligation in AngloSaxon England (London, 1988), p. 177.

78 ASC D E 1016; pp. 150-51.

79 JW vol. 2, pp. 491-92.

8o ASC D E 1016; p. 151. 
incidence of deaths. Amongst the identified Wessex dead were Ealdorman Ælfric of Hampshire and Bishop Eadnoth of Dorchester. ${ }^{81}$

Edmund and Cnut conducted peace negotiations following Assandun and arguably the most significant aspect of the treaty that concluded the war was the division of the country. Wessex, according to the Anglo-Saxon Chronicle, was given to Edmund and Cnut received 'the north part'.82 In partitioning the country, as observed by Timothy Reuter, Edmund and Cnut reopened the political fracture lines that had threatened English unification in the succession crises of 924-25 between Æthelstan and Ælfweard, and that of 955-57 between Eadwig and Edmund's grandfather, Edgar. ${ }^{83}$

\section{Death and Burial in Wessex}

The accord that was reached between Edmund and Cnut lasted approximately one month, curtailed by Edmund dying prematurely on 30 November. His burial in Wessex, at Glastonbury, may have been influenced by the abbey containing the tomb of his grandfather King Edgar, but Edmund may already have had an attachment to the abbey. ${ }^{84}$ On his death-bed, according to William of Malmesbury, Edmund granted the estate of Sturminster Newton (Dorset) and his body to Glastonbury. ${ }^{85}$ While the nature of his relationship with the abbey may have been lost in the succeeding centuries, Edmund's burial at, and donations to Glastonbury, indicate that the community had some significance for him and provide further evidence of his landholdings in Wessex.

The location of Edmund's death is not disclosed by the Anglo-Saxon Chronicle but John of Worcester records that Edmund died in London, and Henry of Huntingdon has him dying in Oxford. ${ }^{86}$ These 12th-century accounts that Edmund died outside Wessex should be regarded as unreliable. The improbability of Edmund dying in London was persuasively argued by Laurence Larson who, early in the 2oth century, cited the city's occupation by the Danes as mitigating against Edmund's presence. Similarly, Larson reasoned it unlikely

\footnotetext{
$81 \quad$ ASC D E F 1016; pp. 152-53.

$82 \quad A S C$ D, p. $15^{2}$.

83 ASC D, pp. 105 and 113; Timothy Reuter, "The Making of England and Germany," in Medieval Europeans: Studies in Ethnic Identity and National Perspectives in Medieval Europe, ed. Alfred P. Smyth (London, 1998), pp. 53-70, at p. 56.

84 Asc, Mss. D and E, pp. ${ }^{12-53}$.

85 The Early History of Glastonbury: An Edition, Translation and Study of William of Malmesbury's 'De Antiquitate Glastonie Ecclesie', ed. John Scott (Woodbridge, 1981), pp. 132-33.

86 JW vol. 2, pp. 492-93; HH, pp. 360-61.
} 
that Edmund would visit Oxford, where the treacherous Eadric had a residence. ${ }^{87} \mathrm{It}$ is more credible that Edmund remained in the region allocated to him by the treaty, and he died in Wessex. One might also reasonably speculate that he died at a royal estate, possibly close to Glastonbury. ${ }^{88}$

Despite the closely contemporary account of the Anglo-Saxon Chronicle of Edmund's burial at Glastonbury it is possible, according to a compelling theory by Martin Biddle and Birthe Kjølbye-Biddle, that some of Edmund's remains were translated to Winchester cathedral where they now reside. A late 12thcentury inscribed marble slab, located on the north side of the south screen of the presbytery, reads: 'HIC: IACET: EDMUNDUS: REX: EPELDREDI: REGIS: FILIUS' (Here lies King Edmund, son of King Æthelred). Edmund's grave-slab at Winchester, suggest Biddle and Kjølbye-Biddle, is either a fabrication or evidence of Edmund's unrecorded re-burial. 89

Edmund's translation to Winchester can be explained by the credible suggestion that Cnut intended the Old Minster to house the remains of his family. Edmund became Cnut's posthumous stepson through the latter's marriage to Emma, and thereby eligible for burial at Winchester. The date of Edmund's reinterment is unknown but, according to Biddle, it was most probably 1031 when Cnut visited Glastonbury. The decorated cloak, which William of Malmesbury has Cnut place on Edmund's tomb, might therefore have been in exchange for removing at least some of Edmund's remains, as might Cnut's recognition of Glastonbury's privileges. ${ }^{90}$

Edmund's translation is also suggested by the West Saxon Genealogical Regnal List, contained in the Liber Vitae of the New Minster and Hyde Abbey, Winchester. The list, composed c.1031, according to Simon Keynes, originally ended with the name of Æthelred but in the 12th-century the kings from Edmund to Stephen were added. ${ }^{91}$ The addition of Edmund's name may indicate that after 1031, the date of Cnut's visit to Glastonbury, Edmund was translated to Winchester.

87 Laurence M. Larson, Canute the Great 995 (circ)—1035 And the Rise of Danish Imperialism During the Viking Age (New York and London, 1912), pp. 99-100.

88 For the identification and discussion of royal estates in Wessex, see Lavelle, Royal Estates.

89 Martin Biddle and Birthe Kjølbye-Biddle, "Danish Royal Burials in Winchester: Cnut and his Family" in Danes in Wessex: The Scandinavian Impact on Southern England, c.8oo-c. 110o, ed. Ryan Lavelle and Simon Roffey (Oxford, 2016), pp. 212-49, at p. 224.

$90 \quad$ WM, GRA, pp. 330-31; Biddle and Kjølbye-Biddle, "Danish Royal Burials," p. 226.

91 The Liber Vitae of the New Minster and Hyde Abbey Winchester, ed. Simon Keynes, Early English Manuscripts in Facsimile 26 (Copenhagen, 1996), p. 83; fol. 14r. 
Edmund's tomb, assuming it is in Winchester, was moved from the Old Minster into the new Norman cathedral. In 1525 the contents of the majority of royal tombs, including Edmund's, were placed in ten wooden chests. Six of these boxes were destroyed in 1642 and their scattered contents placed in two new chests. ${ }^{92}$ When Edmund's mortuary box was inspected in 1797 , it was found to contain the bones of several skeletons, and assigning them to a particular individual was impossible. ${ }^{93}$ However, in 2015 the Dean and Chapter of Winchester announced that forensic investigation of Edmund's ossuary will be conducted by the University of Bristol. At the time of writing, it may be confirmed in the next few years that the final resting place of Edmund Ironside is indeed Wessex.

The majority of the significant events in Edmund Ironside's life occurred in Wessex, he and the region influencing one another. Edmund spent his formative years in Wessex and it provided him the means and opportunity to rebel. Upon assuming the throne, Edmund asserted his kingship in Wessex and re-established English rule in the region. Wessex supplied Edmund with the resources to defend others areas of his kingdom and promote his reputation as a dynamic warrior king. Edmund received Wessex in the division of the country with Cnut, and it is where he died. Wessex was crucial to Edmund's career and kingship, his relationship with the region coming to a cyclical conclusion when it received his mortal remains, not once but twice.

92 For the several translations of Edmund's Winchester tomb, see Biddle and Kjølbye-Biddle, "Danish Royal Burials," pp. 220, Fig.12.6; 226-27; 230-32.

93 J. Milner, The History, Civil and and Ecclesiastical, \& Survey of the Antiquities of Winchester, 2 vols (Winchester, 1809), 2:51. 